\title{
Justification of measures for optimization and prevention with dysplasia of stratified squamous epithelium of the cervix in women of reproductive age
}

\author{
Ra'nokhon Solieva Bakhodir qizi \\ gynecologist, basic doctoral candidate of the Department of \\ Obstetrics and Gynecology No. 1 \\ of the ASMI, Andijan, Uzbekistan solieva_r@mail.ru
}

\author{
Dilfuza Alieva Abdullaevna \\ $\mathrm{MD}$, professor, head of the scientific advisory clinic of \\ Republican specialized scientific and practical medical center of \\ obstetrics and gynecology. Tashkent, Uzbekistan
}

\section{Methods}

In order to achieve the objectives, it is planned to examine women aged 25-49 years, divided into groups: patients with cervical dysplasia (CIN) of various degrees and a group that includes practically healthy women.

All examinations will be carried out on the basis of the Andijan Regional Perinatal Center in the Department of Gynecology, and on the basis of the scientific advisory clinic of Republican specialized scientific and practical medical center of obstetrics and gynecology and on the basis of the Department of Molecular Medicine and Cellular Technologies of the Research Institute of Hematology and Blood Transfusion of the MzRUz.

\section{Results}

Discussion. Despite the large number of studies aimed at developing methods for the early diagnosis of CMM diseases, treatment methods that ensure the absence or minimum number of complications, the carcinogenic potency of background CMM diseases remains unclear. This is where the reserve is located, which allows improving the diagnosis of early manifestations of precancer [3].

\section{ACKNOWLEDGMENT}

With the support of the Ministry of Health of the Republic of Uzbekistan (24-02-2020, No. 8n-d / 89), Andijan State Medical Institute (No. 11-11-2019)

\section{REFERENCES}

[1] Mayorov M.V. Folic acid: when, why, how much? [Electronic resource]. - Access mode: http://lib.komarovskiy.net/folievaya-kislotakogda-zachem-skolko.html.

[2] Shikh E.V., Makhova A.A. Vitamin and mineral complex during pregnancy. M.: GEOTAR-Media; 2016.349 s.

[3] Shikh E.V., Makhova A.A. Questions of choosing the form of folate for the correction of folate status. Obstetrics and gynecology. 2018, No. 8, pp. 33-40.

[4] Botto L.D. et al. International retrospective cohort study of neural tube defects in relation to folic acid recommendations: are the recommendations working? / L.D. Botto, A. Lisi, E. Robert-Gnansia // BMJ. - 2005. - Vol. 330, N 7491. - P. 5 